\title{
Germination of seeds of Fremont cottonwood
}

\author{
JAMES A. YOUNG and CHARLIE D. CLEMENTS
}

Authors are Range Scientists, USDA - ARS, 920 Valley Road, Reno, Nev 89512.

\begin{abstract}
Fremont cottonwood (Populus fremontii S. Watson) is the most important cottonwood species of the southwestern United States. It is usually found in riparian areas of desert riverine systems. Often it is the only tree species in such environments. Lack of Fremont cottonwood seedling recruitment is of concern in many areas. This is especially an issue in river systems infested with the exotic saltceder (Tamarix ramosissima Ledeb.). The proposed suppression of saltceder with a biological control agent, raises the question of the spontaneous recruitment of Fremont cottonwood seedlings if competition is reduced from exotic woody species. Several studies have stressed that geomorphologic-hydrologic conditions in riparian habitats control safesites for Fremont and other cottonwood species seed germination and seedling establishment. Our purpose was to investigate the physiological amplitude for Fremont cottonwood seeds to germinate under a wide range of constant or alternating temperatures. Immediately after dispersal the seeds of Fremont cottonwood are highly germinable. In each of the 3 years that seeds were collected multiple temperature regimes supported $100 \%$ germination. Optimum germination averaged over $90 \%$. At moderate to high warm period temperatures, most germination that will occur does so during the first week after imbibition of moisture. Temperature regimes that supported optimum germination at least once ranged from $0 / 5^{\circ} \mathrm{C}$ to $25 / 40^{\circ} \mathrm{C}$. The regimes that always supported optimum germination were in 2 distinct group: $2 / 25$ and $2 / 30^{\circ} \mathrm{C}$; and a wider dispersed group with 15,25 , or $25^{\circ} \mathrm{C}$ cold period temperatures and 25, 30, or $35^{\circ} \mathrm{C}$ warm period temperatures. There was one outlier at $10 / 15^{\circ} \mathrm{C}$. Fremont cottonwood seeds are highly and rapidly germinable at a wide range of temperatures.
\end{abstract}

Key Words: Populus fremontii, temperature profiles, Tamarix ramosissima, seedbed temperatures

Fremont cottonwood (Populus fremontii S. Watson) is the cottonwood of the southwestern United states (Sudworth 1908). It is closely associated with desert riparian habitats. It is often the tree of riparian areas where streams and rivers extending out from mountainous watersheds into desert valley. Often Fremont cottonwoods form gallery forest over desert streams creating an arboreal environment in sharp contrast to the stark desert or regimented irrigated field that surround the woodland. Historically, the gallery forest often transect the primary sites for irrigated agriculture, ranching, and urbanization (Aspund and Gooch 1988).

Fremont cottonwood reproduction usually is restricted to what has been described as a strand line environment (Siegel and Brock 1990). The natural habitat for Fremont cottonwood seedling recruitment is a portion of the complex geomorphology

Corresponding author jayoung@scs.unr.edu

Manuscript accepted 10 Dec. 02.

\section{Resumen}

"Fremont cottonwood" (Populus fremontii S. Watson) es la especie de "Cottonwood"más importante del suroeste de Estados Unidos, usualmente encontrada en las áreas ribereñas de los sistemas de ríos de los desiertos y a menudo es la única especie de arbórea en estos ambientes. La falta de establecimiento de plántulas de "Fremont cottonwood" es una preocupación en muchas áreas. Esto es especialmente un problema en los sistemas de ríos infestados por la especie invasora "Saltceder" (Tamarix ramosissima Ledeb.). La propuesta de suprimir el "Saltceder" mediante un agente de control biológico produce la pregunta respecto al establecimiento espontáneo de plántulas de "Fremont cottonwood" si la competencia con las especies exóticas leñosas se reduce. Varios estudios has enfatizado que las condiciones geomorfológicas-hidrológicas de los hábitats ribereños controlan los sitios seguros para el "Fremont" y la germinación de la semilla y establecimiento de plántulas de otras especies de "Cottonwood". Nuestro propósito fue investigar la amplitud fisiológica de las semillas de "Fremont cottonwood" para germinar bajo un amplio rango de temperaturas constantes y alternantes. Inmediatamente después de la dispersión las semillas de "Fremont cottonwood" son altamente germinables. En cada uno de los 3 años que las semillas fueron colectadas múltiples regímenes de temperatura produjeron $100 \%$ de germinación, la germinación óptima promedio más del $90 \%$. En periodos de temperatura de moderada a alta la mayoría de la germinación ocurrirá durante la primer semana después de la imbibición de humedad. Los regímenes de temperatura que sostuvieron al menos una vez la germinación óptima variaron de $0 / 5^{\circ} \mathrm{C}$ a $25 / 40^{\circ}$ C. Los regímenes que siempre mantuvieron la germinación óptima estuvieron en 2 grupos distintos $2 / 25$ y $2 / 30^{\circ} \mathrm{C}$; y un grupo de mayor dispersión con 15,25 , or $25^{\circ} \mathrm{C}$ de temperatura en el período frío y 25,30 , or $35^{\circ} \mathrm{C}$ en el período de temperaturas calientes. Hubo un régimen de temperatura fuera del patrón $10 / 15^{\circ} \mathrm{C}$. Las semillas de "Fremont cottonwood"son alta y rápidamente germinables en un amplio rango de temperaturas.

formed by meandering streams subject to seasonal flooding (Aspund and Gooch 1998). The seeds of Fremont cottonwood are wind dispersed to damp gravel, sand, or silt bars where germination occurs and the roots of the seedlings follow the seasonal declining water table. In many areas Fremont cottonwood seedling recruitment has been virtually non-existent. This has been variously attributed to flooding that results in scouring of the riparian area, channelization to reduce damage from flooding, construction of upstream damns to prevent flooding, phreatophytic plant control, invasion by phreatophytic plants especially tamarisk (Tamarix ramosissima Ledeb.), agricultural practices, and over grazing. Most of the studies concerning the lack of 
seedling recruitment have focused on the hydrology of Fremont cottonwood habitats with little attention to the physiology and ecology of the seeds themselves.

The lack of detailed seed physiology research on seeds of Fremont cottonwood is partially a function of the short viability period of the seeds. In laboratory storage, seeds of Fremont cottonwood lost all viability after 7 weeks (Horton et al. 1960). In commercial forest tree nurseries, cottonwood seeds were reported to have markedly reduced emergence if planting was delayed 2 days after harvest (Engstrom 1948).

A major concern with the proposed use of biological control agents to suppress invasive populations of tamarisk is the probability of subsequent recruitment of seedlings of native woody species to form habitat for dependent birds. In a previous paper we reported on the germination of seeds of native willow (Salix sp.) species growing in tamarisk infested areas of the delta of the Walker River in western Nevada (Young and Clements 2003). The only other native woody species in the delta is Fremont cottonwood.

Our purpose was to determine the germination of Fremont cottonwood seeds at a wide range of constant and alternating incubation temperatures. This is a first step in understanding the germination ecology of the seeds of this tree species.

\section{Materials and Methods}

Fremont cottonwood seeds were collected from splitting capsules as soon as seed dispersal was evident. Seed collections were made in 1999, 2000, and 2001. Seeds were collected from as many trees as possible bulked into 1 collection for each year. All collections were made in the delta of the Walker River between Schurz, Nevada and Walker Lake (Latitude north $38^{\circ}$ 53.534', Longitude west $118^{\circ}$, $46.773^{\prime}$ '). The seeds were immediately transported to the laboratory and counted into Petri dishes without removing the abundant silky hairs that cover the seed.

In all experiments 4 replications of 25 seeds each were used in a randomized block design. Seeds were placed on top of non-toxic commercial germination paper in closed Petri dishes and kept wet with tap water. Germination trials were conducted in the dark. Incidental light was received during initial wetting and germination counts. Seeds were considered germinated when the radical emerged $1 \mathrm{~mm}$. Germination counts were made after 1, 2, and 4 weeks. Constant incubation temperatures were 0,2 , and $5^{\circ} \mathrm{C}$ and at 5 degree increments through $40^{\circ} \mathrm{C}$. Alternating regimes included 16 hours at each constant temperature, plus 8 hours at each possible higher temperature per 24 hours. For example, $35 \mathrm{C}$ alternated with $40^{\circ} \mathrm{C}$ only, while $0^{\circ} \mathrm{C}$ alternated with $2,5,10$, $15,20,25,30,35$, and $40^{\circ} \mathrm{C}$. This made a total of 55 constant and alternating temperature regimes (Young et al. 1991).

The germination responses of the accessions of Fremont cottonwood were compared using the following seedbed temperature regime definitions (Young and Evans 1982): a. Very cold: $0 / 0$ (constant $\left.0^{\circ} \mathrm{C}\right), 0 / 2\left(0^{\circ}\right.$ $\mathrm{C}$ for 16 hours and $2^{\circ} \mathrm{C}$ for 8 hours in each 24 hour), $0 / 5$ and $2 / 2^{\circ} \mathrm{C}$.

b. Cold: $0 / 10,0 / 15,2 / 5,2 / 10,2 / 15,5 / 5$, and $5 / 10^{\circ} \mathrm{C}$.

c. Cold fluctuating: $0 / 20$ through $0 / 40^{\circ}$ $\mathrm{C}$ and $2 / 20$ through $2 / 40^{\circ} \mathrm{C}$.

d. Fluctuating: $5 / 35$ through $5 / 40^{\circ} \mathrm{C}$, $10 / 35,10 / 40$, an $15 / 40^{\circ} \mathrm{C}$.

e. Moderate: $5 / 20$ through $5 / 30,10 / 10$ through $10 / 30^{\circ} \mathrm{C}, 15 / 15$ through $15 / 35^{\circ}$ C, $20 / 20$ through $30 / 35^{\circ} \mathrm{C}$, and $25 / 25$ through $25 / 30^{\circ} \mathrm{C}$.

f. Warm: $20 / 40,25 / 35$, and $25 / 40^{\circ} \mathrm{C}$, $30 / 30$ through $30 / 40^{\circ} \mathrm{C}, 35 / 35,35 / 40$, and $40 / 40^{\circ} \mathrm{C}$.

The temperature categories reflect germination environments of field seedbeds based on several years of monitoring in the Great Basin (Evans et al. 1970, Evans and Young 1970, 1972).

Data from each base temperature and its alternating temperature regimes were used to generate a quadratic response surface with estimated means and confidence intervals at the $1 \%$ level of probability (Young et al. 1980, Evans et al. 1982, Palmquist et al. 1987). A number of germination parameters were calculated from the quadratic response surfaces (Table 1) (Young and Evans 1982). These germination parameters were individually subjected to analysis of variance and the means separated by Duncan's Multiple Range Test.

\section{Results and Discussion}

The freshly dispersed seeds of Fremont cottonwood germinate over a wide range

Table 1. Germination parameters calculated from quadratic response surfaces (Young and Evans 1982).

\begin{tabular}{ll}
\hline \hline Calculated parameters & Derivation of parameter \\
\hline Calculated within profile: & \\
Mean germination & Sum divided by 55 \\
Percentage of regimes with germination & $\begin{array}{l}\text { Number with germination divided by } 55 \\
\text { Percentage of regimes with optima }\end{array}$ \\
$\begin{array}{l}\text { Number of regimes with germination not } \\
\text { less than the maximum observed minus } \\
\text { one half the confidence interval divided } \\
\text { by } 55\end{array}$
\end{tabular}

Mean of optima

Maximum germination

Calculated among germination profiles

Frequency of optima
Sum of optima divided by number of regimes with optima

Highest observed germination

Times a given temperature supports optimum germination divided by the total number of test

Purpose

Gross comparison of profiles

Indication of breath of germination response

Provides indication of the breath of temperatures that support optimum germination

Provides a measure of potential germination at most desirable temperatures

Indication of potential viability
Provides an estimate of optimum temperatures for germination with precision 
Table 2. Quadric response surface with calculated percentage germination and confidence interval $(P \leq 0.01)$ for seeds of Fremont cottonwood incubated at 55 constant or alternating temperatures. Seeds collected from Walker River Delta in $2000{ }^{1}$

\begin{tabular}{|c|c|c|c|c|c|c|c|c|c|c|}
\hline \multirow{2}{*}{$\begin{array}{l}\text { Cold period } \\
\text { temperature }\end{array}$} & \multicolumn{10}{|c|}{$\begin{array}{l}\text { Percentage germination } \\
\text { Warm period temperature } \mathrm{C}\end{array}$} \\
\hline & 0 & 2 & 5 & 10 & 15 & 20 & 25 & 30 & 35 & 40 \\
\hline & $30+8$ & $75 \pm 8$ & {$[100+8 *$} & $100+8 *$ & $100+8 *$ & ) & $100+8 *$ & $100+8 *$ & 10 & $8 * 1$ \\
\hline $\begin{array}{l}0 \\
2\end{array}$ & $30 \pm 0$ & $73 \pm 10$ & $\begin{array}{l}100 \pm 0 \\
97 \pm 8 *\end{array}$ & {$\left[100 \pm 8^{*}\right.$} & $100 \pm 8^{*}$ & $100 \pm 8^{*}$ & $\begin{array}{l}100 \pm 8^{*} \\
100 \pm 8^{*}\end{array}$ & $\begin{array}{l}100 \pm 8^{*} \\
100 \pm 8^{*}\end{array}$ & $\begin{array}{l}100 \pm 8^{*} \\
100 \pm 8 *]\end{array}$ & $\begin{array}{r}\left.100 \pm 8^{*}\right] \\
96 \pm 10^{*}\end{array}$ \\
\hline 5 & & & $95 \pm 9 *$ & {$\left[100 \pm 8^{*}\right.$} & $100 \pm 8^{*}$ & $100 \pm 8^{*}$ & $100 \pm 8^{*}$ & $100 \pm 8^{*}$ & $100 \pm 8^{*}$ & $\left.100 \pm 8^{*}\right]$ \\
\hline 10 & & & & {$\left[100 \pm 8^{*}\right.$} & $100 \pm 8 *$ & $100 \pm 8^{*}$ & $100 \pm 8^{*}$ & $100 \pm 8 *]$ & $95 \pm 10^{*}$ & $88 \pm 10$ \\
\hline 15 & & & & & {$\left[100 \pm 8^{*}\right.$} & $100 \pm 8^{*}$ & $100 \pm 8 *$ & $100 \pm 8^{*}$ & $100 \pm 8 *]$ & $30 \pm 10$ \\
\hline 20 & & & & & & {$\left[100 \pm 8^{*}\right.$} & $100 \pm 8^{*}$ & $100 \pm 8 *]$ & $90 \pm 10$ & $30 \pm 12$ \\
\hline 25 & & & & & & & $77 \pm 10$ & $96 \pm 10^{*}$ & $45 \pm 10$ & $12 \pm 12$ \\
\hline 30 & & & & & & & & $16 \pm 10$ & $4 \pm 12$ & $6 \pm 12$ \\
\hline 35 & & & & & & & & & $0 \pm 12$ & $0 \pm 12$ \\
\hline & & & & & & & & & & $0 \pm 12$ \\
\hline
\end{tabular}

${ }^{T}$ Number following the mean is one half of the confidence interval as determined from regression equations used to develop response surface (Palmquist et al. 1987). The maximum calculated germination is enclosed by brackets $\{[]$. * indicates mean not lower than the maximum germination minus one half of its confidence interval, our definition of optimum germination.

of constant or alternating temperatures (Table 2). We present the complete response surface for the germination of seeds collected in 2000 to illustrate the basic data set. A staggering $53 \%$ of the temperature regimes produced $100 \%$ germination. This is a level of viability unprecedented in our experience with seeds collected from native stands. The number of regimes with $100 \%$ germination was much higher in 2000 compared to 1999 and 2001 (data not shown). In early May of 2000, just a few weeks before the Fremont cottonwood seeds were mature, a severe late frost occurred. Germination of seeds of 2 species of willow (Salix) collected in the same area as the Fremont cottonwood seeds was severely reduced (Young and Clements 2003).

Mean germination of the profiles and number of regimes supporting germination for the 3 years of testing did not signifi-

Table 3. Germination parameters for seeds of Fremont cottonwood calculated from quadratic response surfaces. Seeds of all accessions from Walker River Delta. ${ }^{1}$

\begin{tabular}{lccc}
\hline \hline $\begin{array}{l}\text { Germination } \\
\text { Parameter }\end{array}$ & 1999 & $\begin{array}{c}\text { Accession } \\
2000\end{array}$ & 2001 \\
\hline Profile characteristics & $---1 \%)$ & \\
$\quad$ Mean & 75 & 76 & 72 \\
$\quad$ Regimes with some germination & 92 & 94 & 96 \\
$\quad$ Mean of optima & 92 & 99 & 99 \\
$\quad$ Regimes with optima & $42 \mathrm{~b}$ & $69 \mathrm{a}$ & $58 \mathrm{ab}$ \\
$\quad$ Maximum & 100 & 100 & 100 \\
Seedbed temperature categories & & & \\
$\quad$ Very cold & $28 \mathrm{~b}$ & $70 \mathrm{a}$ & 91 \\
$\quad$ Cold & 87 & 99 & 83 \\
$\quad$ Cold fluctuating & 86 & 99 & 83 \\
$\quad$ Fluctuating & 86 & 99 & $65 \mathrm{~b}$ \\
$\quad$ Warmer & $77 \mathrm{a}$ & $15 \mathrm{~b}$ & 97 \\
$\quad$ Moderate & 87 & 93 & \\
\hline
\end{tabular}

'Means within rows followed by the same letter are not significantly different at the 0.01 level of probability as determined ny Duncan's Multiple Range Test. No letter indicates no significant differences. cantly ( $\mathrm{P} \geq 0.01$ ) differ (Table 3 ). Regimes with some germination is an important parameter because even a limited germination potential under harsh seedbed temperature conditions maybe mean the difference between some seedling recruitment and complete failure. If you could successfully recruit 1 Fremont cottonwood seedling per linear kilometer of riparian habitat on an annual basis stand renewal rates might be considered sustainable. This is just a hypothetical estimate which is not based on any data, but it illustrates the importance of germination at a very wide range of incubation temperatures and the increased chance of establish if the seeds of a moderately long lived perennial woody species can germinate at some level at temperature extremes. For Fremont cottonwood seeds produced in 2000 in the Walker River delta, there was $30 \%$ germination at a constant $0^{\circ} \mathrm{C}$ and
$100 \%$ germination at $0 / 40^{\circ} \mathrm{C}\left(0^{\circ} \mathrm{C}\right.$ for 16 hours and $40^{\circ} \mathrm{C}$ for 8 hours in each 24 hour period) (Table 2 ).

For seeds produced in 2000 and 2001 , over $50 \%$ of the temperature regimes supported optimum germination (Table 3 ). Our definition of optimum germination is not lower than the maximum observed minus one half of the confidence interval $(P \geq 0.01)$. In all years the optima averaged over $90 \%$. In all 3 years the maximum observed germination was $100 \%$.

The categories of seedbed temperatures which we use were developed for terrestrial seedbeds during the late fall or early spring germination period (Evans et al. 1970). Fremont cottonwood seed germination has to occur soon after dispersal in late May and early June. It is doubtful that very cold seedbed temperatures would occur during the germination $(0,2,0 / 2$, and $0 / 5^{\circ} \mathrm{C}$ ). Freezing night time temperatures are possible, but not probable. The Fremont cottonwood seeds collected in 2000 averaged $70 \%$ germination at these temperatures and had $30 \%$ germination at $0^{\circ} \mathrm{C}$ (Table 2). The seeds collected in all 3 years had very high germination at the cold category of seedbed temperatures (Table 3). The seeds collected in 2000 that had very high germination at very cold and cold temperatures had significantly ( $P$ $\geq 0.01$ ) lower germination at warmer seedbed temperatures (Table 3).

Fremont cottonwood seeds combine the requirement to fall on a moist seedbed with a very short viability half life. This makes speed of germination an important parameter. During the first week of incubation with 0 to $5^{\circ} \mathrm{C}$ cold period temperatures the warm period temperatures had to be $15^{\circ} \mathrm{C}$ or above to produce $50 \%$ of the total germination observed with 4 weeks 
Table 4. Percentage of total germination of Fremont cottonwood seeds that occurred during the first week of incubation at each of the 55 temperatures tested. Average for all seeds collected from Walker River Delta 1999, 2000, and 2001.

\begin{tabular}{|c|c|c|c|c|c|c|c|c|c|c|}
\hline \multirow{2}{*}{$\begin{array}{l}\text { Cold period } \\
\text { temperatures }\end{array}$} & \multicolumn{10}{|c|}{$\begin{array}{l}\text { Percentage of total germination } \\
\text { Warm period temperatures } C\end{array}$} \\
\hline & 0 & 2 & 5 & 10 & 15 & 20 & 25 & 30 & 35 & 40 \\
\hline (C) & -- & ---- & 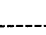 & --- & 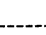 & 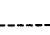 & - & 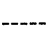 & ------ & 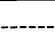 \\
\hline 0 & 0 & 27 & 19 & 17 & 50 & 65 & 90 & 94 & 98 & 68 \\
\hline 2 & & 6 & 30 & 29 & 64 & 75 & 94 & 97 & 98 & 64 \\
\hline 5 & & & 6 & 35 & 62 & 75 & 90 & 97 & 97 & 91 \\
\hline 10 & & & & 58 & 81 & 92 & 90 & 90 & 99 & 100 \\
\hline 15 & & & & & 2 & 98 & 95 & 98 & 100 & 100 \\
\hline 20 & & & & & & 95 & 98 & 99 & 100 & 97 \\
\hline 25 & & & & & & 95 & 98 & 99 & 100 & 97 \\
\hline 30 & & & & & & & 89 & 99 & 100 & 100 \\
\hline 35 & & & & & & & & & 98 & 100 \\
\hline 40 & & & & & & & & & & 0 \\
\hline
\end{tabular}

Table 5 Percentage of total germination of Fremont cottonwood seeds that occurred during the second week of incubation at each of the 55 temperatures tested. Average for all seeds collected from Walker River Delta 1999, 2000, and 2001.

\begin{tabular}{|c|c|c|c|c|c|c|c|c|c|c|}
\hline \multirow{2}{*}{$\begin{array}{l}\text { Cold period } \\
\text { temperatures }\end{array}$} & \multicolumn{10}{|c|}{$\begin{array}{l}\text { Percentage of total germination } \\
\text { Warm period temperatures } \mathrm{C}\end{array}$} \\
\hline & 0 & 2 & 5 & 10 & 15 & 20 & 25 & 30 & 35 & 40 \\
\hline (C) & $-\cdots$ & 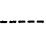 & 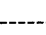 & ---- & 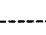 & - & & & & --- \\
\hline 0 & 0 & 30 & 40 & 50 & 50 & 35 & 7 & 5 & 0 & 32 \\
\hline 2 & & 48 & 46 & 52 & 32 & 20 & 6 & 3 & 2 & 36 \\
\hline 5 & & & 69 & 64 & 23 & 25 & 10 & 3 & 3 & 5 \\
\hline 10 & & & & 40 & 11 & 8 & 9 & 3 & 0 & 0 \\
\hline 15 & & & & & & 8 & 2 & 5 & 1 & 0 \\
\hline 20 & & & & & & 5 & 2 & 1 & 0 & 3 \\
\hline 25 & & & & & & & 9 & 0 & 0 & 0 \\
\hline 30 & & & & & & & & 2 & 1 & 2 \\
\hline 35 & & & & & & & & & 0 & 0 \\
\hline 40 & & & & & & & & & & 0 \\
\hline
\end{tabular}

of incubation (Table 4). A constant $10^{\circ} \mathrm{C}$ would also produce above $50 \%$ of the observed germination. To get above $90 \%$ of the observed germination in the first week the cold period temperature had to be 10 through $20^{\circ} \mathrm{C}$ alternating with at least $20^{\circ} \mathrm{C}$ or any cold period temperature alternating with $25^{\circ} \mathrm{C}$. To reach $100 \%$ of the observed germination in the first week cold period temperatures had to be $10^{\circ} \mathrm{C}$ or above and the warm period temperatures in the 35 or $40^{\circ} \mathrm{C}$ categories. In interpreting these results it is important to remember the data is presented as the percentage of the total observed that occur in the first week of incubation. For example a $25 / 40^{\circ} \mathrm{C}$ temperature regime had $100 \%$ of the observed germination in the first week (Table 4), for the seed collected in 2000 the total germination was only $12 \%$.
A $0 / 10^{\circ} \mathrm{C}$ incubation temperature had only $17 \%$ of the total observed germination in the first week (Table 4), the total germination for 2000 seed after 4 weeks was $100 \%$ (Table 2). At high temperatures during the warm period, the germination you are going to observe happens very quickly, but it is not necessarily high germination.

During the second week of incubation

Table 6. Percentage of total germination of Fremont cottonwood seeds that occurred during the third and fourth weeks of incubation at each of the 55 temperatures tested. Average for all seeds collected from Walker River Delta 1999, 2000, and 2001.

\begin{tabular}{|c|c|c|c|c|c|c|c|c|c|c|}
\hline \multirow{2}{*}{$\begin{array}{l}\text { Cold period } \\
\text { temperatures }\end{array}$} & \multicolumn{10}{|c|}{$\begin{array}{l}\text { Percentage of total germination } \\
\text { Warm period temperatures } C\end{array}$} \\
\hline & 0 & 2 & 5 & 10 & 15 & 20 & 25 & 30 & 35 & 40 \\
\hline (C) & -- & ----. & - & 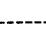 & . & & & & & \\
\hline 0 & 100 & 45 & 41 & 33 & 0 & 0 & 3 & 0 & 2 & 0 \\
\hline 2 & & 44 & 29 & 19 & 4 & 5 & 0 & 0 & 0 & 2 \\
\hline 5 & & & 25 & 1 & 15 & 0 & 0 & 0 & 0 & 0 \\
\hline 10 & & & & 2 & 8 & 0 & 1 & 7 & 1 & 0 \\
\hline 15 & & & & & 0 & 0 & 0 & 1 & 0 & 0 \\
\hline 20 & & & & & & 0 & 0 & 0 & 0 & 0 \\
\hline 25 & & & & & & & 2 & 1 & 0 & 0 \\
\hline 30 & & & & & & & & 0 & 0 & 1 \\
\hline 35 & & & & & & & & & 0 & 0 \\
\hline 40 & & & & & & & & & & 0 \\
\hline
\end{tabular}


Table 7. Frequency that a given temperature regime supported optimum germination of seeds of Fremont cottonwood for all accessions tested.

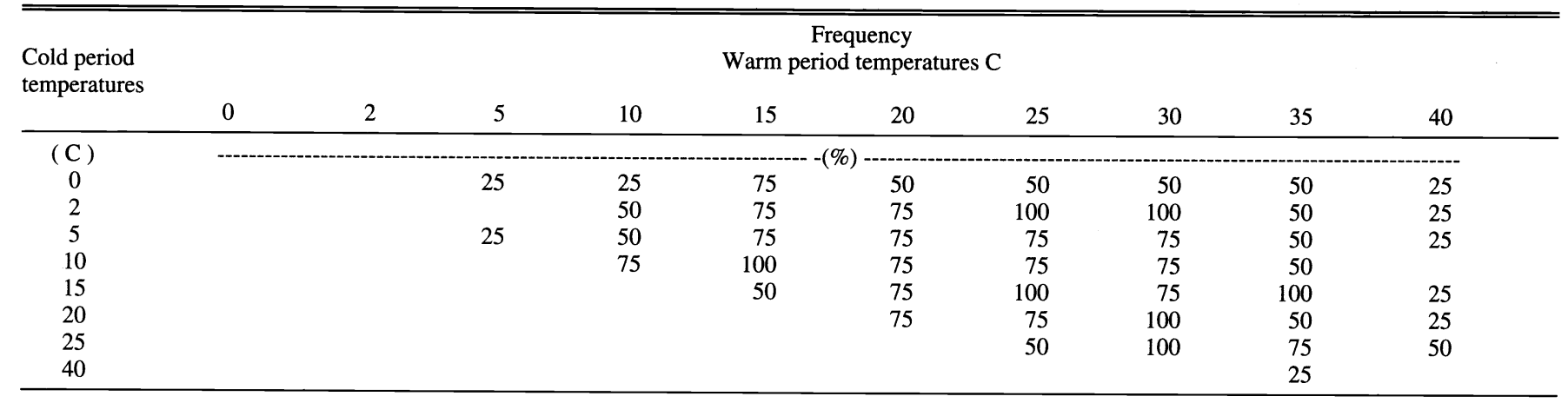

germination at the higher incubation temperatures was minimal and sporadic (Table 5). An exception was $0 / 40$ and $2 / 40^{\circ} \mathrm{C}$ where about two thirds of the total observed germination occurred during the first week and one third during the second week of incubation (Table 4 and 5). The low cold period temperatures alternating with cool warm period temperatures had moderate amounts of their total observed germination during the second week of incubation (Table 5). Only a constant $0^{\circ} \mathrm{C}$ had all the observed germination during the third and fourth weeks of incubation (Table 6). Smaller amounts of germination occurred for the cooler incubation temperatures. These results indicate that with moderate to high warm period temperatures, most of the germination of Fremont cottonwood seeds that will occur does so during the first week after they imbibe moisture, even if cold period temperatures are quite cold.

With so many temperatures supporting optimum germination it is expected that the frequency of optima would be spread over a wide range (Table 7 ). Temperature regimes from a cold $2 / 5^{\circ} \mathrm{C}$ to a warm $25 / 40^{\circ} \mathrm{C}$ supported optimum germination at least once. The regimes that always supported optima were found in 2 distinct groupings. The first was $2 / 25$ and $2 / 30^{\circ} \mathrm{C}$ (Table 7). The second group was $20 / 25$ and $20 / 35^{\circ} \mathrm{C}, 20 / 30^{\circ} \mathrm{C}$, and $30^{\circ} \mathrm{C}$. There was one outlier at $10 / 15 \mathrm{C}$. With the exception of the outlier, the warm period temperature had to be 25 or $30^{\circ} \mathrm{C}$.

Viability, dormancy, and speed of germination do not appear to be limiting for germination of Fremont cottonwood seeds from the Walker River delta populations. This information reinforces the need to understand the moisture relations of available seedbeds during the seed dispersal period to understand the limiting factors for Fremont cottonwood seed germination.

\section{Literature Cited}

Aspund, K. K. and M. T. Gooch. 1988. Geomorphology and distributional ecology of Fremont cottonwoods (Populus fremontii) in a desert riparian canyon. Desert Plants 9(1):17-27.

Engstrom, A. 1948. Growing cottonwoods from seed. J. Forestry 46:130-132.

Evans, R. A. and J. A. Young. 1970. Plant litter and establishment of alien annual species in rangeland communities. Weed Sci. 18:697-703.

Evans, R. A. and J. A. Young. 1972. Microsite requirements for establishment of alien annual species in rangeland communities. Weed Sci. 20:350-356.

Evans, R. A., D. A. Easi, D. N. Book, and J. A. Young. 1982. Quadratic response surface analysis of seed germination trials. Weed Sci. 30:411-416.

Evans, R. A., H. R. Holbo, R. E. Eckert, Jr., and J. A. Young. 1970. Functional environment of downy brome communities in relation to weed control and revegetation. Weed Sci. 18:154-162.

Horton, J. S., F. C. Mounts, and J. M. Kraft. 1960. Seed germination and seedling establishment of phreatophyte species. Station Paper No. 48. USDA, Forest Serv., Rocky Mountain Forest and Range Exp.Sta., Fort Collins, Colo.

Palmquist, D. E., R. A. Evans, and J. A. Young. 1987. Comparative analysis of temperature response surfaces. pp. 97-103 In G. W. Frasier and R. A. Evans (eds.) Seed and Seedbed Ecology of Rangeland Plants. USDA, Agr. Res. Ser., Washington, D.C.

Siegel, R. S. and Brock, J. H. 1990. Germination requirements of key southwestern riparian species. Desert Plants 10(1):3-9.

Sudworth, G. B. 1908. Forest trees of the Pacific slope. USDA, Forest Service, Washington. D. C.

Young, J. A. and C. D. Clements. 2003. Germination of seeds of willow species from a desert riparian system. J. Range Mange. 56:496-500.
Young, J. A. and R. A. Evans. 1982 Temperature profiles for germination of cool season grasses. ARR-W-72, USDA, ARS, Oakland, Calif. 92 p.

Young, J. A., D. E. Palmquist, and R. A. Evans. 1991. Temperature profiles for germination of cool season grasses. ARR-W-72, USDA, ARS, Oakland, Calif. 92p.

Young, J. A., B. L. Kay, H. George, and R. A. Evans. 1980. Germination of three species of Atriplex. Agronomy J. 72:705-709. 